\title{
Rapid and simple CZE-UV method for quality control of B1 and B6 vitamins in drugs and dietary supplements
}

\author{
Special Issue Article \\ Matuskova M. ${ }^{1}$, Cizmarova I. ${ }^{1}$, Chalova P.1,2, Mikus P. ${ }^{1,3}$, Piestansky J., ${ }^{1,3 凶}$ \\ Received 15 June, 2021, accepted 17 June, 2021 \\ Abstract The application of hydrodynamically closed capillary zone electrophoresis combined with convenient ultraviolet (UV) detection \\ allows fast, simple, environmentally friendly and cost-effective analysis of ions or ionisable molecules. This technique has been \\ used to determine two selected B vitamins (thiamine, pyridoxine) in various drug formulations. The developed method was \\ characterised by excellent validation parameters, such as linearity, precision, accuracy, limit of detection and limit of quantification. \\ The total time of analysis was lower than $13.5 \mathrm{~min}$. The results indicate that the method is suitable for implementation in routine \\ quality control of selected B vitamins in pharmaceutical and food samples.
}

Keywords capillary zone electrophoresis - hydrodynamically closed system - ultraviolet detection - thiamine - pyridoxine - quality control

\section{INTRODUCTION}

Quality, safety and efficacy are the main drug attributes. The therapeutic effect depends on the exact amount of an active substance present in the medicine. Doses higher than therapeutic ones are often responsible for adverse and toxic effects. On the other hand, the use of lower doses cannot achieve the demanded benefit to human health. It is known that the active substances undergo decomposition processes due to the environmental effects. The quantity of the original drug can be reduced and the related degradation products can form. Typically, they have a negative impact on the drug quality and could represent a potential health risk. Therefore, measurement of the active substance in medicine is necessary to ensure its high quality.

Thiamine (THI) and pyridoxine (PYR) belong to a wide group of $B$ vitamins. As active substances in drugs, they are indicated in nervous system diseases - for example, polyneuropathy, neuritis, herpes zoster, myalgia and states with $\mathrm{B}_{1}$ and $\mathrm{B}_{6}$ deficiency (Calderón-Ospina \& Nava-Mesa, 2020). They are also offered as dietary supplements in order to provide them in sufficient amounts. THI and PYR can be administered in various dosage forms - injections, tablets, film-coated tablets, capsules or capsules with modified release.

Electrophoretic separation methods, especially capillary zone electrophoresis (CZE), seem to be useful in the analysis of active substances. CZE is simple to use, economical and ecological (consumption of low amount of sample and organic solvents) and is characterised by a high separation efficiency (Řemínek \& Foret, 2021). These facts make it suitable for routine use in pharmaceutical analysis, which is demonstrated in some papers published by our laboratory group dealing with the analysis of antigripal drugs (Maráková et al., 2013), inflammatory bowel disease drugs (Maráková et al., 2017), vitamins (Maráková et al., 2014) or drugs used to treat tobacco use disorder (Pieštanský et al., 2013).

We have recently proposed a CZE method in a hydrodynamically closed separation system to determine THI and PYR in commercial beverages and food supplements (Matušková et al., 2020). Here, we used this method (with 
some minor modifications) to analyse THI and PYR content in various dosage forms and dietary supplements (Fig. 1a-c).

\section{MATERIALS AND METHODS}

Thiamine hydrochloride, pyridoxine hydrochloride and chemicals used for electrolyte system solution preparation ( $\gamma$-aminobutyric acid [GABA], acetic acid [HAc], methylhydroxyethylcellulose [m-HEC]) were obtained from Sigma-Aldrich (Steinheim, Germany) and Serva (Heidelberg, Germany). Deionised water $(18.2 \mathrm{M} \Omega \mathrm{cm}$ ) was used for the preparation of all solutions. The experiments were performed on EA 102 apparatus (Villa Labeco, Spisska Nova Ves, Slovakia) in a CZE single-column arrangement. A separation column was provided with a 300- $\mu$ m internal diameter (i.d.) polytetrafluorethylene (PTFE) capillary tube of total length $90 \mathrm{~mm}$ and a contactless conductivity detector. The background electrolyte (BGE) was composed of $25 \mathrm{mM} \mathrm{GABA}$ $+50 \mathrm{mM} \mathrm{HAc}+0.5 \% \mathrm{~m}$-HEC $(\mathrm{pH}=3.7)$. The samples were injected by a 200-nL internal sample loop of the injection valve of the analyser. All experiments were performed in a constant current mode. The driving current was $50 \mu \mathrm{A}$. An ultraviolet (UV) spectrophotometric absorbance detector (Knauer, Berlin, Germany) was connected to an on-column photometric detection cell via optical fibres. The detector was set at $260 \mathrm{~nm}$.

Preparation of the sample for analysis depended on the pharmaceutical formulation. Here, three types of formulations were analysed - injections (Milgamma NA inject; Wörwag Pharma, Böblingen, Germany), film-coated tablets (B-komplex Sanofi; Zentiva, Prague, Czech Republic) and capsules (Diclovit, G.L. Pharma, Lannach, Austria). Preparation of injections was accompanied only by simple dilution with demineralised water at an appropriate concentration level. Pharmaceuticals formulated as film-coated tablets and capsules were crushed into a fine powder. An amount of the powder equivalent to the weight of one tablet (or capsule) was transferred to a 100$\mathrm{mL}$ volumetric flask using demineralised water. The solution was sonicated for $\mathbf{3 0 ~ m i n , ~ f i l t r a t e d ~ u s i n g ~ W h a t m a n ~ f i l t e r ~ p a p e r ~}$ No.1 and diluted (if needed) with demineralised water. These solutions were then directly analysed using CZE as described above.

\section{RESULTS AND DISCUSSION}

At first, it was necessary to prove the proposed method for the demanded purpose. Therefore, we validated the modified CZE-UV method according to the ICH Q2(R1) guideline (ICH Harmonised Tripartite Guideline, 2005) recommendations. All resulting statistical data and performance parameters of the CZE-UV method are summarised in Table 1.

The method provided favourable parameters such as separation efficiency $(\mathrm{N})$ and sample loadability, which resulted in sub- $\mu \mathrm{g} / \mathrm{mL}$ limit of detection (LOD) and limit of quantification (LOQ) values. An illustrative electropherogram
Table 1. Performance parameters of the CZE-UV method.

\begin{tabular}{|c|c|c|}
\hline & Thiamine & Pyridoxine \\
\hline$t_{m}(\min )$ & 7.01 & 11.02 \\
\hline $\mathrm{RSD}_{\mathrm{tm}}(\%), \mathrm{n}=6$ & 0.28 & 0.76 \\
\hline $\mathrm{RSD}_{\text {area }}(\%), \mathrm{n}=6$ & 2.28 & 8.60 \\
\hline $\mathrm{a}(\mathrm{mAU})$ & 134.76 & -39.09 \\
\hline $\operatorname{RSD}_{a}(\%), n=6$ & 2.27 & 1.33 \\
\hline $\mathrm{b}(\mathrm{mAU} / \mu \mathrm{g} \mathrm{mL})$ & 94.77 & 36.22 \\
\hline $\operatorname{RSD}_{b}(\%), n=6$ & 0.49 & 0.29 \\
\hline$r^{2}$ & 0.9996 & 0.9990 \\
\hline Linear range $(\mu \mathrm{g} / \mathrm{mL})$ & $0.5-100$ & $1-100$ \\
\hline $\mathrm{LOD}(\mu \mathrm{g} / \mathrm{mL})$ & 0.08 & 0.15 \\
\hline $\mathrm{LOQ}(\mu \mathrm{g} / \mathrm{mL})$ & 0.25 & 0.50 \\
\hline $\mathrm{N}$ & 7900 & 6400 \\
\hline $\mathrm{R}$ & \multicolumn{2}{|c|}{8.81} \\
\hline
\end{tabular}

$\angle O D$ and $L O Q$ were calculated as the signal $(S)$ to noise $(N)$ ratios to be $3 \times S / N$ and $10 \times S / N$, respectively. Separation efficiency $(N)$ was calculated according to the equation $N=5.545^{*}(t)$ $\left.w_{1 / 2}\right)^{2}$, where $t_{m}$ is the migration time and $w_{1 / 2}$ is the full width at half maximum of the peak. The calibration curve is expressed by the equation $y=b . x+a . R S D_{\text {tm }}$ and $R S D_{\text {arep }}$ were calculated from the samples at $L O Q$ concentration level. Resolution $(R)$ was calculated according to the equation $R=1.18^{*}\left(t_{2}-t_{1}\right) /\left(w_{1 / 2 T H 1}+\right.$ $\left.w_{1 / 2 P Y R}\right)$, where $t_{2}$ is the migration time of PYR, $t_{1}$ is the migration time of THI, $w_{1 / 2 \mathrm{THI}}^{1 / 2}$ is the full width at half maximum of the THI peak and $w_{1 / 2 \text { PYR }}$ is the full width at half maximum of the PYR peak.

obtained from the analysis of THI and PYR standards at 0.25 $\mu \mathrm{g} / \mathrm{mL}$ concentration level (LOQ of THI and concentration close to LOD of PYR) is presented in Fig. 1d. The enhanced sample loadability resulted from the use of wide-bore (300 $\mu \mathrm{m}$ i.d.) separation capillary tubes, which are typical for a hydrodynamically closed separation system. In comparison to our previous work (Matušková et al., 2020), the use of shorter separation column resulted in faster analysis of THI and PYR. Excellent linearity of the calibration lines (concentration range $0.5-100 \mu \mathrm{g} / \mathrm{mL}$ ) is indicated by the coefficient of determination $\left(r^{2}\right)$ values. Acceptable repeatability was confirmed by the values of relative standard deviations (RSD) of migration time $\left(\mathrm{RSD}_{\mathrm{tm}}\right)$, peak area $\left(\mathrm{RSD}_{\text {area }}\right)$, intercept $a$ $\left(\mathrm{RSD}_{\mathrm{a}}\right)$ and slope $b\left(\mathrm{RSD}_{\mathrm{b}}\right)$ of the calibration lines. Critical factor of the validation procedure was the recovery parameter. The recovery experiment was performed by spiking the tested pharmaceutical dosage forms with THI and PYR standards at three concentration levels. Representative records, shown in Fig. 1e, illustrate the sample profile characteristics for $\mathrm{THI}$ and PYR in the original and spiked (at three concentration levels 5,10 and $25 \mu \mathrm{g} / \mathrm{mL}$ ) commercial drug Diclovit.

Recovery values, calculated for the THI and PYR detection response in the standard (water) and tested drug matrices (injection solution, film-coated tablets, capsules; see Fig. 
a)

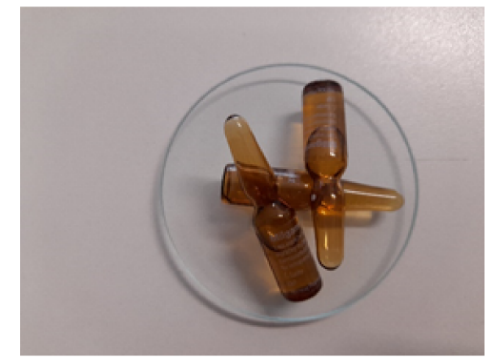

d)

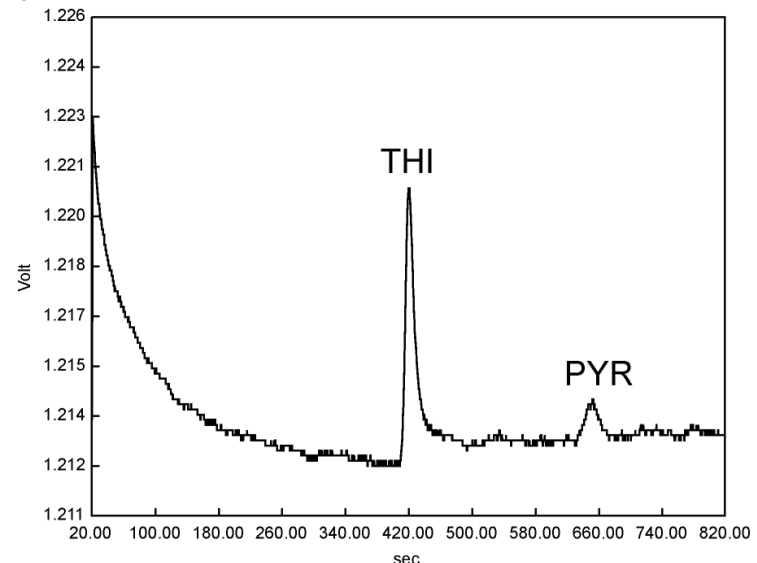

b)

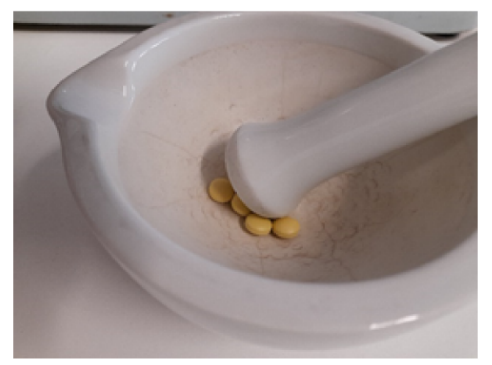

e)

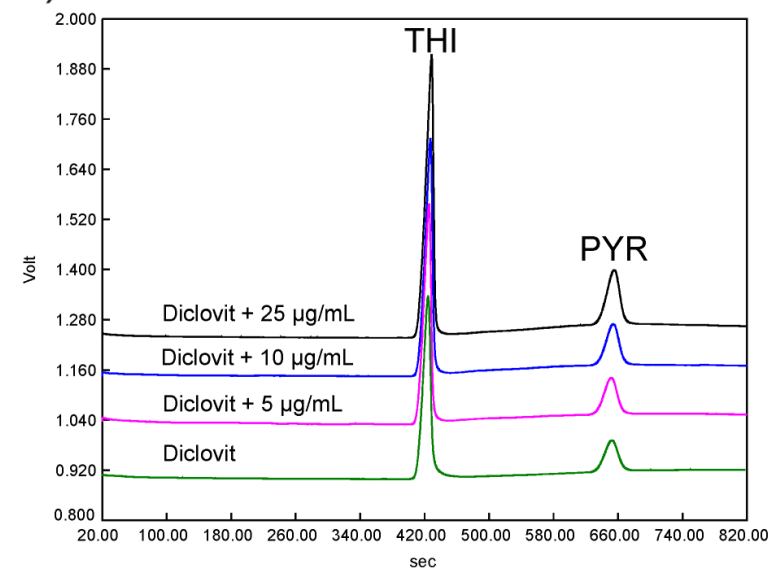

Figure 1. Analysis of THI and PYR in various pharmaceutical dosage forms - a) injection solutions Milgamma NA, b) film-coated tablets B-komplex Sanofi and c) capsules Diclovit. d) Illustrative electropherogram of THI and PYR at the concentration level 0.25 $\mu \mathrm{g} / \mathrm{mL}$. e) IIlustrative electropherogram obtained from the CZE-UV analysis of non-spiked and spiked drug Diclovit. The spiked concentrations of THI and PYR were 5, 10 and $25 \mu \mathrm{g} / \mathrm{mL}$. The injected volume was $200 \mathrm{~nL}$.

$1 \mathrm{a}-\mathrm{c})$, were in the range $95 \%-115 \%$ for $\mathrm{THI}$ and $90 \%-107 \%$ for PYR. This indicated acceptable effect of the matrix on the analyte signal and acceptable accuracy of the method.

After the successful validation procedure, the proved CZEUV method was applied to determine the content of THI and PYR in real pharmaceutical samples. The obtained results are summarised in Table 2 . The measured data were in good agreement with the declared content. Only in case of film-coated tablets (B-komplex Sanofi), the determined content of $\mathrm{THI}$ was slightly higher than $15 \%$ in comparison to the declared one. This variation might be caused due to changes during the storage and manufacture. However, B-komplex Sanofi is classified as a dietary supplement. For such preparation, there is no strict adherence to the active compound content.

In conclusion, the present work illustrates the potential of simple CZE-UV method performed in hydrodynamically closed separation system for the quality control of THI and PYR present in pharmaceutical samples. The advantages of such an analytical system were demonstrated by the excellent performance parameters of the CZE-UV method and its successful application in the drug and dietary supplements' quality control area. This method is suitable for the automation
Table 2. THI and PYR concentrations in three pharmaceutical samples determined by the CZE-UV method.

\begin{tabular}{|c|c|c|c|c|}
\hline \multirow[b]{2}{*}{ Preparation } & & \multicolumn{3}{|c|}{ Parameters } \\
\hline & & $\begin{array}{l}\text { Found } \pm \\
S D(\mu g / m L)\end{array}$ & $\begin{array}{c}\mathrm{RSD}(\%), \\
\mathrm{n}=3\end{array}$ & $\begin{array}{c}\text { Declared } \\
(\mu \mathrm{g} / \mathrm{mL})\end{array}$ \\
\hline \multirow{2}{*}{$\begin{array}{l}\text { Milgamma } \\
\text { NA (inj) }\end{array}$} & THI & $53.15 \pm 0.26$ & 0.49 & 50 \\
\hline & PYR & $23.01 \pm 0.23$ & 0.98 & 25 \\
\hline \multirow{2}{*}{$\begin{array}{l}\text { Diclovit } \\
\text { (cps) }\end{array}$} & THI & $50.81 \pm 1.27$ & 2.50 & 50 \\
\hline & PYR & $43.18 \pm 1.07$ & 2.48 & 50 \\
\hline \multirow{2}{*}{$\begin{array}{l}\text { B-komplex } \\
\text { Sanofi } \\
\text { (tbl flm) }\end{array}$} & THI & $11.59 \pm 0.18$ & 1.56 & 10 \\
\hline & PYR & $5.52 \pm 0.50$ & 9.00 & 5 \\
\hline
\end{tabular}

and miniaturisation and it has promising potentialities to be used in the reference and routine pharmaceutical laboratories. Owing to being a rapid, cheap, available and reliable analysis, the presented CZE-UV approach represents a suitable alternative to the well-established analytical methods used in drug and food analysis. 


\section{ACKNOWLEDGMENTS}

This work was supported by the projects VEGA 1/0463/18, APVV-15-0585, KEGA 027UK-4/2020, FaF UK/2/2021, FaF UK/3/2021 and the grant of Comenius University UK/235/2021 and was carried out in the Toxicologic and Antidoping Center at the Faculty of Pharmacy Comenius University.

\section{References}

[1] Calderón-Ospina CA, Nava-Mesa MO. B vitamins in the nervous system: Current knowledge of the biochemical modes of action and synergies of thiamine, pyridoxine, and cobalamin. CNS Neurosci Ther. 2020; 26: 5-13.

[2] ICH Harmonised Tripartite Guideline: Validation of Analytical Procedures: Text and Methodology. Step 4 Version. European Medicines Agency, November 2005 (http://www.ich.org/cache/ compo/276-254-1.html). Accessed June 9, 2021.

[3] Maráková K, Pieštanský J, Havránek E, Mikuš P, Simultaneous analysis of vitamins $B$ in pharmaceuticals and dietary supplements by capillary electrophoresis hyphenated with triple quadrupole mass spectrometry. Pharmazie. 2014; 69: 663-668.

[4] Maráková K, Pieštanský J, Mikuš P. Determination of drugs for Crohn's disease treatment in pharmaceuticals by capillary electrophoresis hyphenated with tandem mass spectrometry. Chromatographia. 2017; 80: 537-546.

\section{CONFLICT OF INTEREST STATEMENT}

The authors do not have any conflict of interest concerning the present work.

[5] Maráková K, Pieštanský J, Veizerová L, Galba J, Dokupilová S, Havránek E, Mikuš P. Multidrug analysis of pharmaceutical and urine matrices by on-line coupled capillary electrophoresis and triple quadrupole mass spectrometry. J Sep Sci. 2013; 36: 18061816.

[6] Matušková M, Čižmárová I, Mikuš P, Pieštanský J. Stanovenie tiamínu a pyridoxínu vo výživových doplnkoch a nápojoch jednoduchou metódou kapilárnej zónovej elektroforézy v spojení s UV detekciou. Čes. Slov. Farm. 2020; 69: 237-243.

[7] Pieštanský J, Maráková K, Veizerová L, Galba J, Mikuš P. Stanovenie vareniklínu v lieku Champix ${ }^{\circledR}$ dvojdimenzionálnou kapilárnou elektroforézou v spojení s UV detekciou. Čes. Slov. Farm. 2013; 62: 270-275.

[8] Řemínek R, Foret F, Capillary electrophoretic methods for quality control analyses of pharmaceuticals: A review. Electrophoresis. 2021; 42: 19-37. 